\title{
How Cultural Understanding Influences Business Success in Middle East and North Africa (MENA)
}

\section{Dr. Gholam Ali Shaykhian, NASA}

Ali has received a BS degree in Electronics, a Master of Science (M.S.) degree in Computer Systems and a second M.S. degree in Operations Research from the University of Central Florida and has received a Ph.D. degree in Operations Research from the Florida Institute of Technology (FIT). His research interests include knowledge management, data mining, object-oriented methodologies, design patterns, software safety, genetic and optimization algorithms. Dr. Shaykhian is a professional member of the American Society for Engineering Education (ASEE), serving as the past Program Chair for the Minorities in Engineering Division. He has served as a chair, vice-chair, program chair, and program committee member for numerous conferences of ASEE.

\section{Dr. Jinan Ziade,}

I have a PhD in Organizational Leadership with emphasis in IST from University of Phoenix, and an MBA from the same university. I have over 7 years of extensive leadership experience in advertising, marketing, strategies, and project team lead. Currently serving as Program Chair of Guild volunteer at St. Jude Medical Center and working with Memorial Foundation on philanthropic endeavors. My research interest include knowledge of cultural differences and leadership practices within global organizations and problem solving. Developed a leadership practices model that provides a suitable framework and salient business strategy component for corporations seeking to expand successfully.

\section{Dr. Mohd A. Khairi, Najran University}

I, Mohamed Khairi, my bachelor degree in computer science. I did my Masters in system science from University of Ottawa, Canada. My PH.D was in "Master Data Management" from University of Phoenix. I have over 20 years of experience in IT industry - ten of them with Microsoft in Redmond, WA. Currently I'm assistant professor at University of Najran. In addition of teaching and Research I'm coordinator of graduation projects and field training for computer and information system college. 


\title{
How cultural understanding influences business success in Middle East and North Africa (MENA)
}

\begin{abstract}
Technological innovations in communication, transportation, and the internationalization of national markets has led leaders of corporations of all sizes to increase interconnectedness and relationships within all aspects of life. Distance is no longer a barrier, the world has been shrinking and hierarchical geopolitics are flatter; that is, the world has become smaller and national boundaries matter less. This increased integration has benefited economic growth and the interrelationship among various cultures and people. Economic interdependence has led to increased competition among corporations to achieve sustainability and expand demand for products and services to meet customers' expectations.
\end{abstract}

Geopolitical boundaries do not restrict seemingly borderless businesses in the fields of information access, education, markets, capital, products, and services. This situation is very different from 19th century railroad transportation and 20th century mass-production manufacturing in which competition operated mainly amongst neighboring regions. Three emblematic factors characterize globalization: the technological revolution, cross-regional dialogue, and cultural diversity, which have proved to be catalysts for the growth of business. Developments in technology have caused organizations to change the business culture and change how people communicate between organizations. Friedman [10] linked information advancements to the world he described as flattened and shrinking, driven by culturally diverse organizations that value diversity of people. Noting technology's transformative potential, Friedman [10] explained, "With interconnectivity, work could be moved around to the four corners of the world through the creation of a global platform for a global workforce of people" (p. 67).

The specific problem is that American multinational organizations operating in MENA may lose business opportunities due to the lack of business leaders' understanding of cultural differences. American global organizations possibly encounter weakened organizational performance because of the shortage of culturally competent American business leaders regarding the cultures of the MENA region [19][22][25]. This paper exposes the importance of increased insight into cultural differences, which may enable leaders to achieve substantial results by appropriately preparing employees to accomplish organizational missions. Focusing on cultural differences could assist educators, leaders to develop strategic cross-cultural approaches to transform educators, managers into global strategic leaders. Leaders may need to seek a deeper understanding of the peculiarities of the host culture and style of leadership and management, and to look for continual improvement.

Introduction: Globalization enabled United States corporations to increase the company's share of the global market [30] as well as assert a company's presence in the global economy. Altman [4] suggested that success in securing increased global market share indicates evidence of corporate adaptations to a global marketplace environment characterized by a rapid pace, broad scope of evolutionary changes, rapid diffusion of innovation, and unpredictable 
changes. Friedman [10] perceived internationalization of business activity as an advantage, stimulating further high-tech development and investments that provide a platform for delivering intellectual work globally. Leaders seeking to invest abroad may need to assimilate practices to carry out or avoid when attempting to form business relationships in MENA. A United States federal government agency, the Overseas Private Investment Corporation (OPIC), has been instrumental in promoting and assisting United States multinational corporations operating overseas.

A survey conducted in 2014 shows that $52 \%$ of multinational corporations (MNCs) surveyed aspire to increase business operations globally and only $15 \%$ planned to develop leaders with cultural competence [30]. This discrepancy may lead to a loss in pool of global leadership and a critical gap in cross-cultural skills [30]. For an organization to enhance organizational performance and remain globally competitive using cross-cultural understanding as an effective tool to benefit from commerce and global acceptance, it must ensure that its business leaders gain competencies in cross-cultural skills.

The general problem is a shortage of culturally competent leaders in multinational corporations (MNCs) able to meet the unique challenges of global leadership [8][18][32]. Caligiuri and Tarique [7] professed that business leaders of most global companies should view cross-cultural literacy as the most essential competency in international markets. An inadequate understanding of cultural and business differences may jeopardize performance of organizations doing business across borders [2][7][12][16][23][28]. American global organizations may lose business opportunities and possibly encounter weakened organizational performance because of the shortage of culturally competent American business leaders regarding the cultures of the MENA region [18][19][22][25][32].

Religious differences, Islamic culture, and religious values. Scholars should consider the impact of religion on leadership practices [21][34]. In a study of the three Abrahamic monotheistic religions of Judaism, Christianity, and Islam, Kriger and Seng [21] found that some basic premises of the monotheistic religions shape the behavior of leaders and organizational cultures. In contrast, Van Buren and Greenwood [33] asserted that leadership style moderates the effect of personal spiritual beliefs and spiritual practices of leaders on strategic decision-making processes. Each religion has a particular ethical standpoint toward the content of religiosity, which may comfort the decision-maker and assist the decision-making process [34]. Personal spiritual beliefs affect the behavior and strategic decisions of top-level leaders and such beliefs affect the measurement and adjustment of the spiritual climate of the leaders' organizations. Other researchers have claimed that spiritual and religious beliefs influence leadership style in the way leaders develop new skills and provide information relied upon in the workplace [27][34].

As cultures vary in different Middle Eastern countries, leaders of the region may interpret the company's business practices and frame personal reactions according to the individual's cultural background and assumptions [11]. Islam is the prevailing religion in the MENA countries, and leadership style tends to be highly authoritarian because Islam promotes obedience, loyalty, and respect for seniority as work-related values [20]. Similarly, where 
Muslim observance is strong, fatalism plays an important part in the daily lives of organizational members [17].

Chu and Mustafa [9] debated that some of the practices, such as strict gender divisions in traditional Islam, are not tenets of the faith but a misguided tradition. Such attitudes toward authority imply that Muslim leaders may tend more toward the laissez faire, autocratic, and charismatic leadership styles. Lack of political freedom and liberties and the opacity of regional autocracies tend to block democratic reforms. In Western culture, management styles tend to emphasize performance [13]. For individualists, priorities are set based on individual and immediate family considerations [6].

Islam influences family relations and orientation, hierarchical distance, and collectivism resulting in dominant paternalism. For collectivists, the needs of the group far outweigh needs of a few individuals [6]. Ali [3] stated Islam can play an influential role and can contribute to shaping the mindset of individual and group behavior among Arabs. Islam governs all aspects of life within Arab society and Ali ascribed certain behavioral characteristics to its members: (a) a deep sense of family honor, (b) pay more respect to elderlies and (c) respect for Arabic as the language of the Qur'an, the text of Islamic faith.

Some research has shown that Arab leaders are bureaucratic, paternalistic, and autocratic with a weak future orientation. For example, Abdalla and Al-Homoud [1] found effective Islamic leaders are individuals who are charismatic and righteous religious role models who lead followers to the leader's ideals. In contrast, Ali [3] argued Christianity places an emphasis on authority figures as sources of power in organizations whereas Islam focuses more on flatter and leaner organizational structures.

In the Arab world, variations in history, religion, and tribal affiliations add diversity to the cultures of the various countries [5][35]. Although not all Arabs are Muslim, Arab culture and tribalism within Islam inspires the Arab way of life in the Middle East and other regions in the world [26]. The central objective of Islam is to promote human welfare through socioeconomic justice and adherents consider it one of the most important teachings of Islam. Distribution of wealth is one of the five pillars of Islam, along with faith, prayer, fasting, and pilgrimage to Mecca, which indicates the connection of spiritual and economic practices, and the need for social justice while promoting economic development.

The aim of Islamic monotheism is to associate social justice with the collective good and includes democracy, human rights, equality, and critical thought. Islamic philosophy promotes ethical principles through religious requirements that influence business decision-making processes, so Muslims associate principles with faith in Islam. Islamic law of human conduct regulates many aspects of Muslims' behavior and influences individuals' ethical behavior toward kin, opportunities, individual practices, ethics, peer pressure, administrative necessities, government regulations, and community demands to promote ethical conduct. Economically, critics of globalization recognize that globalization contradicts the principle of social justice. The economics of globalization depends on the accumulation of wealth and the pursuit of one's selfinterest. 
Collectivistic Arab values influence Muslims, making Muslims more collectivistic than individualistic [15]. Loyalty in a collectivist culture is paramount. Hofstede [14][15] determined that Islam correlates strongly with the dimensions of uncertainty avoidance and power distance. Research findings from different countries provided a mixed response on the power distance measure. For example, in Pakistan where Islam is the majority religion, power distance is comparatively low and an expected characteristic because Islam preaches equality among all Muslims regardless of economic status [15]. In contrast, though Islamic traditional values prevail in all facets of business in most Arabic countries [24][29] found that in predominantly Arab countries, power distance is very high because people expect a chasm to exist between leaders and followers.

Research Question and Sub-Question: The general problem is a shortage of culturally competent leaders in multinational corporations (MNCs) able to meet the unique challenges of global leadership [8][18][32]. For an organization to enhance organizational performance and remain globally competitive using cross-cultural understanding as an effective tool to benefit from commerce and global acceptance, it must ensure that its business leaders gain competencies in cross-cultural skills. The premise of the qualitative phase of this study focused on the central question: What are the lived experiences of business leaders and decision makers working outside the United States, including changes in management practices and differences discovered between individualistic and collectivistic cultures?

A purposive sampling was used to recruit the qualitative participants who met minimum criteria. Seventeen participants met the criteria (lived experiences of international assignment(s) in MENA) and provided the answers to the interview questions. The study includes a subquestion that give depth and detail in relation to the phenomenological research question. The purpose of the qualitative research question (RQ) and sub-research questions (SRQ) was to gather participants lived experiences of American global expansion. An open-ended interview questions developed from the research questions.

SRQ 1: How do business leaders and decision makers working outside the United States describe the experience of changes in management practices and difference discovered between individualistic and collectivist? SRQ1 was designed to collect interviewee experiences in changes in management practices of business leaders and decision-makers working outside the United States in a cultural environment that is dominantly collectivist as opposed to individualistic managerial characteristic in the USA. The impact of cultural factors such as language and communication barriers, behavior, and religious diversity may interfere with the ability to effectively communicate, decrease potential risks, or mitigate possible business operations loss in MENA.

IQ 1: How does your experience working outside the United States differ from working in the United States or other International destinations? Describe what you have observed in terms of changes in management practices when working outside the United States? IQ 1was formulated to delve into SRQ1 to help understand business leaders' perception of cross-cultural differences in management practices in an environment marked by cultural diversity. Differences in culture can significantly affect leadership practices [18][32]. The common theme derived from 
the responses of participants from IQ 1 was Theme 1: Cross-cultural experience facilitates cultural diversity. Table 1 show the relationship of themes to research question.

Table 1: Relationship of Themes to Research Question

Research Questions $\quad$ Themes

RQ1: What are the lived experiences of business leaders and decision makers working outside the United States, including changes in management practices and differences discovered between individualistic and collectivistic cultures?

SRQ 1: How do business leaders and decision makers working outside of the United States describe the experience of changes in management practices and difference discovered between individualistic and collectivist cultures?
Theme 1: Cross-cultural facilitates cultural diversity.

Theme 1: Cross-cultural facilitates cultural diversity.

Summary: The participant's responses indicated that $95 \%$ of participants shared similar experience regarding major advantages and difficulties faced while managing diversity. Expatriates living in MENA came with different cultural backgrounds and cultural awareness, lifestyles, and behavioral patterns, bringing different life experiences to the workplace. When discussing diversity management, participants felt managers have to understand the various cultures within the company, experiences, and intelligently manage diversity. Participants' responses show that differences in culture can significantly affect leadership practices. Crosscultural understanding became an issue and modifications became apparent in order for individuals to operate in a diverse cultural work environment.

Many participants found differences in business cultures affected their relationship with other people from different backgrounds. Thirteen of the seventeen participants mentioned their ability to integrate into the local community, while four of the seventeen (RP006, RP009, RP010, and RP017) experiences represented unique barriers that resulted in misinterpreting or misunderstanding others' perspectives. Fifteen participants stated that working in global business settings required them to understand varied perspectives of cultural and behavioral background to be able to cope with the host culture. Participants suggested that such understanding helped leaders to apply their insights and respond more competently in business situations.

RP002 stated, "I started to learn about cultures differences and etiquette, such fear start to diminish and started to gain some confidence and shared my struggles with my team members". RP005 stated, "When working outside the USA one must be patient and cognizant of the different approaches to decision making and culture or failure will ensue. We must be aware of 
local custom and procedures if we are to succeed". In addition, RP009 stated, "Though working abroad brought many challenges, yet it can be a great introductory to learn how people incorporate a variety of backgrounds, ideas, and personalities".

RP011 made an interesting comment about the effect of good communication skills to "maintain a good relationship." The responses from the participants show a need for leaders to develop learning skills in this new environment in order to communicate effectively. Nevertheless, if knowledge is not well communicated good information may not be shared effectively. Participants RP003, RP014, and RP015, on the other hand, listed some practices that translated into a negative perception to adapting to a new culture, including the ongoing difficulty with social changes and lifestyle limitation. Results from this study shows the importance of intercultural competencies and leadership diversity practices, and perceptions of conducting business in MENA. Such discussion could assist organizational leaders in adopting a global mindset to help reduce risks, ambiguities, and uncertainties associated with operating in MENA.

\section{References}

1. Abdalla, I. A., \& Al-Homoud, M. A. (2001). Exploring the implicit leadership theory in the Arabian Gulf States. Applied Psychology: An International Review, 50(4), 503-531. http://dx.doi.org/10.1111/14640597.00071

2. Abbe, A., Gulick, M., \& Herman, J. L. (2007). Cross-cultural competence in Army leaders: A conceptual and empirical foundation (U.S. Army Research Institute for the Behavioral and Social Sciences). Retrieved from: http://www.dtic.mil

3. Ali, A. J. (1996). Organizational development in the Arab world. Journal of Management Development, 15(5), 4-21. http://dx.doi.org/10.1108/02621719610117213

4. Altman, W. (2009). Marketing in rising economies. Engineering \& Technology 4(11), 76-77 (17509637). http://dx.doi.org/10.1049/et.2009.1120

5. Bradley, D. B., III, Brown, J. E., \& Rubach, M. J. (2010). Iraqi business culture: An expatriate's view. Journal of International Business Research, 9(2), 21-36. Retrieved from http://www.alliedacademies.org/public/journals/journaldetails.aspx?jid=15

6. Burrell, D. N., Safi, A., Rahim, E., Justice, P., \& Walker, R. (2010). An applied research case study analysis of managerial leadership's ability to positively influence tolerance of religious and international cultural diversity in the United States workplace business environment. John Ben Shepperd Journal of Practice Leadership, 5, 91 111. Retrieved from http://aa.utpb.edu

7. Caligiuri, P., \& Tarique, I. (2012). Dynamic cross-cultural competencies and global leadership effectiveness. Journal of World Business, 47(4), 612-622. http://dx.doi.org/10.1016/j.jwb.2012.01.014

8. Chin, O. C., \& Gaynier, L. P. (2006). Global Leadership competence: A cultural intelligence perspective. Paper presented at the fourth annual conference of MBAA International (formerly Midwest Business Administration Association), Chicago, IL. Retrieved from http://www.csuohio.edu/sciences/dept/psychology/graduate/diversity/GlobalLeadership\%2011206.pdf 
9. Chu, J., \& Mustafa, N. (2005). Her turn to pay. Time International (Canada Edition), 165(13), 43.

10. Friedman, T. L. (2005). The world is flat. New York, NY: Farrar, Straus and Giroux.

11. Greaves, S. (2012). A primer of Middle Eastern leadership culture. Journal of Strategic Security, 5(4), 99-227. http://dx.doi.org/10.5038/1944-0472.5.4.7

12. Haile, S., Jones, M. D., \& Emmanuel, T. (2009). Challenges facing expatriate performance abroad. International Journal of Business Research, 7(5), 100-105.

13. Hodgetts, R. M., Luthans, F., \& Doh, J. P. (2006). International management: Culture, strategy, and behavior (6th ed.). New York, NY: McGraw-Hill Irwin.

14. Hofstede, G. (1980). Culture's consequences: International differences in work related values (vol. 5). Thousand Oaks, CA: Sage Publications.

15. Hofstede, G. (2001). Culture's consequences: Comparing values, behaviors, institutions, and organizations across nations (2nd ed.). Thousand Oaks, CA: Sage.

16. Holt, K., \& Seki, K. (2012). Global leadership: A development shift for everyone. Industrial \& Organizational Psychology, 5(2), 196-215. doi.org/10.1111/j.1754-9434.2012.01431.x

17. Hughes, R. L., Ginnett, R. C., \& Curphy, G. J. (2009). Leadership: Enhancing the lessons of experience (6th ed.). New York, NY: McGraw-Hill Irwin.

18. Jacokes, L. E. (1996). "Driving out fear" helps workplace thrive. Grand Rapids Business Journal, 14(23), 15.

19. Kalliny, M. (2010). Are they really different from U.S.: A comparison of Arab and American newspaper advertising. Journal of Current Issues \& Research in Advertising, 32(1), 95-108. http://www.tandfonline.com/toc/ujci20/current\#.U20_vqLDXhE

20. Kalliny, M., Saran, M., Ghanem, S., \& Fisher, C. (2011). Cultural differences and similarities in television commercials in the Arab world and the United States. Journal of Global Marketing, 24(1), 41-57. http://dx.doi.org/10.1080/08911762.2011.545719

21. Kriger, M., \& Seng, Y. (2005). Leadership with inner meaning: A contingency theory of leadership based on the worldviews of five religions. The Leadership Quarterly, 16(5), 771-806. http://dx.doi.org/10.1016/j.leaqua.2005.07.007.

22. Kuntz, J., Elenkov, D., \& Nabirukhina, A. (2013). Characterizing ethical cases: A cross-cultural investigation of individual differences, organizational climate, and leadership on ethical decision-making. Journal of Business Ethics, 113(2), p317-331. http://dx.doi.org/ 10.1007/s10551-012-1306-6

23. Repeckiene, A., Kvedaraite, N., \& Jankauskiene, V. (2011). Intercultural competence as precondition for cultural diversity management. Economics \& Management, 16, 882-891. Retrieved from http://www.ktu.lt/lt/mokslas/zurnalai/ekovad/16/1822-6515-2011-0882.pdf

24. Robertson, C. J., Al-Khatib, J. A., Al-Habib, M., \& Lanoue, D. (2001). Beliefs about work in the Middle East and the convergence versus divergence of values. Journal of World Business, 36(3), 223-244. http://dx.doi.org/ 10.1016/s1090-9516(01)00053-0.

25. Schmitz, C.L., Stakeman, C., \& Sisneros, J. (2001). Educating professionals for practice in a multinational society: Understanding oppression and valuing diversity. Families in Society, 82(6), 612. http://dx.doi.org/10.1606/1044-3894.160 
26. Segelhorst, K. (2009). An introduction to Arab culture: A brief synopsis for U.S. soldiers. Infantry, 98(1), 39. http://www.benning.army.mil/infantry/magazine/

27. Sengupta, S. S. (2010). Correlates of spiritual orientation \& managerial effectiveness. Indian Journal of Industrial Relations, 45(5), 45-60. Retrieved from http://www.srcirhr.com/ijir.php

28. Shen, J., \& Lang, B. (2009). Cross-cultural training and its impact on expatriate performance in Australian MNEs. Human Resource Development International, 12(4), 371-386. doi: 10.1080/13678860903135763.

29. Sidani, Y., \& Thornberry, J. (2010). The current Arab work ethic: Antecedents, implications, and potential remedies. Journal of Business Ethics, 91(1), 35-49. http://dx.doi.org/10.1007/s10551-009-0066-4.

30. Sinar, E., \& Verdone, J. (2014). Global leadership forecast 2014-2015. DDI. Retrieved from https://www.ddiworld.com/glf2014

31. Sidhu, J., Commandeur, H., \& Volberda, H. W. (2007). The multifaceted nature of exploration and exploitation: Value of supply, demand, and spatial search of innovation. Organization Science, 18(1), 20-38. http://dx.doi.org/10.1287/orsc.1060.0212

32. Tay, S. (2010). America's call to globalization. Forbes. Retrieved from http://www.forbes.com/2010/09/22/asiaamerica-globalization-markets-economy-book-excerpt-simon-tay.html

33. Van Buren III, H. J., \& Greenwood, M. (2013). The genesis of employment ethics. Journal of Business Ethics, 4, 707-719. http://dx.doi.org/ 10.1007/s10551-013-1722-2

34. Webb, B., Bopp, M., \& Fallon, E. A. (2011). A qualitative study of faith leaders' perceptions of health and wellness. Journal of Religion and Health, 52(1), 235-246. http://dx.doi.org/ 10.1007/s10943-011-9476-6

35. Wunderle, W. (2007, March-April). How to negotiate in the Middle East. Military Review, 8, 33-37. Retrieved from http://usacac.army.mil/CAC2/MilitaryReview/repository/MREditions2007-English.xml 